\title{
Erratum to: Prey selection by resident common bottlenose dolphins (Tursiops truncatus) in Sarasota Bay, Florida
}

Elizabeth J. Berens McCabe • Damon P. Gannon •

Nélio B. Barros • Randall S. Wells

Published online: 7 January 2010

(C) Springer-Verlag 2010

\section{Erratum to: Mar Biol}

DOI 10.1007/s00227-009-1371-2

Unfortunately, an error occurred in the genus and species names of common bottlenose dolphin. In the title, it should be Tursiops truncatus instead of tursiops truncatus. In the table and figure captions, it should be Tursiops truncatus instead of Tursiops truncates.

The online version of the original article can be found under doi:10.1007/s00227-009-1371-2.

E. J. Berens McCabe $(\varangle) \cdot$ N. B. Barros $\cdot$ R. S. Wells

Chicago Zoological Society, c/o Mote Marine Laboratory,

1600 Ken Thompson Parkway, Sarasota, FL 34236, USA

e-mail: eberens@mote.org

D. P. Gannon

Bowdoin Scientific Station, Bowdoin College,

6500 College Station, Brunswick, ME 04011, USA

N. B. Barros

Department of Biology, Portland State University,

P.O. Box 751, Portland, OR 97207, USA 